\title{
Padrões e singularidades na midiatização de ONGs sobre a Crise da Água em São Paulo, Brasil
}

\author{
Jane M. Mazzarino ${ }^{1}$, Luciana Turattio ${ }^{2}$, Margarita Rosa Gavíria Mejia ${ }^{1}$, Denise Bisolo Scheibe ${ }^{3}$
}

\author{
${ }^{1}$ Docente permanente do Programa de Pós-Graduação Ambiente e Desenvolvimento (PPGAD) da Universidade do Vale do Taquari (Univates). \\ ${ }^{2}$ Docente permanente do Programa de Pós-Graduação Ambiente e Desenvolvimento (PPGAD) e do Programa de Pós-Graduação em Sistemas Ambientais \\ Sustentáveis (PPGSAS) da Universidade do Vale do Taquari (Univates). \\ ${ }^{3}$ Graduanda em Psicologia da Universidade do Vale do Taquari (Univates) \\ *Autor correspondente: janemazzarino@univates.br
}

Recebido em 16 de maio de 2017. Aceito em 24 de maio de 2018. Publicado em 20 de junho de 2018.

REsumo - O presente artigo trata de um problema que alcançou seu ápice entre 2013 e 2015, atingindo milhões de pessoas e diferentes setores sociais e produtivos. Dada a proporção do acontecimento, recebeu ampla cobertura da mídia de massa, reverberando nas redes sociais. O objetivo do artigo é analisar a midiatização feita por organizações não governamentais (ONGs) sobre a crise da água em São Paulo. A questão norteadora do estudo delimita uma investigação sobre como a crise hídrica paulista é enquadrada pelas ONGs ambientalistas, a partir de sua abordagem midiática no ambiente virtual. Tendo como categoria principal de análise os enquadramentos da crise, analisaram-se seis elementos: imagens e links, contextualização, responsabilização, fontes e agendamento. O estudo é qualitativo, focado na análise textual das notícias.

Palavras-chave: Midiatizaçáo; Organizações Não Governamentais; Crise Da ÁGua.

Patterns and singularities in the mediation of NGOs on the water crisis in São Paulo, Brasil

Aвstract - This article deals with a problem that reached its apex between 2013 and 2015, affecting millions of people and different social and productive sectors. Given the proportion of the event, it received wide mass media coverage, reverberating in social networks. The objective of this article is to analyze the mediatization made by non-governmental organizations (NGOs) on the water crisis in São Paulo. The guiding question of the study delimits an investigation about how the São Paulo water crisis is framed by environmentalists NGOs, based on its mediatic approach in the virtual environment. The crisis frameworks being the main category of the analysis, six elements were analyzed: images and links, contextualization, accountability, sources and scheduling. The study is qualitative, focused on textual analysis of the news.

Keywords: MediATIZATION; NON GOVERnMENTAL OrGANIZATIONS; W ATER CRISIS.

Modelos y singularidades en la mediatización de ONGs sobre la Crisis del agua en São Paulo, Brasil

REsumen - Este estudio discurre sobre un problema que alcanzó su ápice entre 2013 y 2015, afectando a millones de personas y a diferentes sectores sociales y productivos. Debido a su proporción, la crisis del agua en el Estado de São Paulo recibió amplia cobertura de los medios de comunicación de masa, reflejando en las redes sociales. El objetivo del estudio fue analizar la mediatización, hecha por organizaciones no gubernamentales(ONG), sobre la crisis del agua en São Paulo. La cuestión principal del estudio es como la crisis hídrica paulista fue enmarcada por las ONGs ambientales, a partir del enfoque de los medios de comunicación virtuales. Adoptando los marcos de la crisis como la principal categoría de análisis, se analizaron seis elementos: imágenes y links, contexto, responsabilidad, fuentes y programación. El estudio es cualitativo con foco en el análisis textual de las noticias. 
Palabras clave: Mediatización. Organizaciones no gubernamentales. Crisis del agua.

\section{INTRODUÇÃO}

A crise da água no estado de São Paulo alcançou seu ápice entre 2013 e 2015, atingindo milhões de pessoas e diferentes setores sociais e produtivos. Dada a proporção do acontecimento, recebeu ampla cobertura da mídia de massa, reverberando nas redes sociais.

O volume de notícias cresceu gradativamente a partir de 2013, 2014 e 2015, sendo que em 2016 diminuiu a sua aparição nas diferentes mídias. As notícias salientaram a negação da crise pelos gestores; oposições entre posicionamentos; uso de debates sobre reservatórios, reposições e transposições; acompanhamento do clima e da questão hídrica; comparativos com outras regiões; dados dos gestores da água nos estados e no país; o racionamento, a má qualidade da água e o preço pago pelo seu fornecimento; possíveis soluções, entre outros temas.

O objetivo do artigo é analisar a midiatização feita por organizações não governamentais (ONGs) sobre a crise da água em São Paulo. A questão norteadora do estudo delimita uma investigação sobre como a crise hídrica paulista é enquadrada pelas ONGs ambientalistas, a partir de sua abordagem midiática no ambiente virtual. Tendo como categoria principal de análise os enquadramentos da crise, analisaram-se seis elementos: imagens e links, fontes, contextualização, responsabilização e agendamento.

Noticiar é uma função do campo jornalístico, permeada de normas e regras, que resulta em enquadramentos dados aos acontecimentos sociais. Enquadrar tem o sentido de criar quadros para fazer ver a realidade, como mapas para o olhar. A notícia, enquanto um quadro sobre o acontecimento faz a ligação entre fontes, jornalistas e receptores, resultando em uma visão partilhada dos acontecimentos (Santos 1997).

Isto porque por meio da notícia enquadram-se acontecimentos em significados familiares ao público, o que requer mapas socioculturais compartilhados entre todos os envolvidos na comunicação midiática. É próprio dos modos de fazer da mídia tornar os acontecimentos significativos e inteligíveis para o público. Portanto, a notícia é um encontro que se dá entre os envolvidos em um processo sociossemiótico.

A midiatização dos acontecimentos interfere na formação da opinião pública e nas trocas comunicativas cotidianas entre os cidadãos, assim como na interpretação coletiva dos problemas, podendo gerar envolvimento político, aproximação e troca de experiências, além de construção de confiança mútua, da descoberta de pontos em comum e da vontade de compor com o coletivo. Ou seja, pode-se potencializar a emergência de capital comunicacional, definido por Matos (2009 28) como “[...] o potencial intersubjetivo de intercompreensão e negociação recíproca de entendimentos e pontos de vista diante de uma situação que exija a ação coordenada para a solução de impasses e problemas".

A construção de um capital comunicacional voltado para problemas socioambientais pode determinar o surgimento do que se pode denominar capital comunicacional socioambiental, baseado no debate público, na partilha de valores relativos à cidadania ambiental, na percepção da interdependência entre todas as formas de vida, na formação de laços de pertencimento entre as pessoas e entre elas e o meio e a criação de objetivos comuns para melhoria das condições socioambientais (Mazzarino 2010).

\section{Material e MÉtodos}


O estudo, caracterizado como qualitativo, exploratório e descritivo, partiu da coleta de documentos midiáticos, publicados ao longo de todo o ano de 2014, por quatro ONGs nos seus sites oficiais no Brasil sobre a crise da água em São Paulo. As ONGs escolhidas foram Greenpeace Brasil e World Wide Fund Nature (WWF Brasil), com inserção internacional, e as nacionais SOS Mata Atlântica (SOS) e Instituto Socioambiental (ISA). Como o interesse era analisar a midiatização da crise da água, para realizar a coleta definimos que seriam usadas as palavras "crise Cantareira" e "crise da água", já que averiguou-se que com estas palavras usadas individualmente chegava-se aos mesmos resultados. A busca gerou a coleta de 35 publicações, sobre as quais realizou-se análise discursiva qualitativa, procedendo-se à descrição dos materiais e sua interpretação, guiada por categorias mistas, algumas definidas a priori e outras a posteriori (Moraes 2007). Elegeu-se como macrocategoria os enquadramentos da crise feitos pela midiatização das ONGs. Esta categoria é composta por seis elementos: imagens e links, fontes, contextualização, responsabilização e agendamento.

Trata-se de um estudo das gramáticas de produção midiáticas, baseado no entendimento que o discurso é um conjunto significante, formado por gramáticas ou conjunto de invariantes discursivos, as quais deixam marcas incrustadas no suporte textual midiático que expressam suas condições. As condições de produção referem-se à geração de um discurso, já as condições de reconhecimento referem-se aos efeitos de um discurso (recepção), em que as regras de reconhecimento formam gramáticas outras. Como as condições sociais de produção nunca são as mesmas condições do reconhecimento esta diferenciação funda o conceito de circulação, marcado por defasagens e desvios de sentido (Verón 2004). Busca-se investigar as marcas presentes nas gramáticas de produção dos discursos midiáticos das ONGs sobre a crise da água paulista. Os resultados são apresentados em três etapas: a primeira descritiva, a segunda refere-se a uma síntese comparativa dos dados e, por último, como conclusão, realiza-se sua interpretação.

\section{REsultados}

Ao se realizarem comparações da midiatização da crise da água pelas ONGs, considerou-se relevante caracterizar minimamente as ONGs, o que foi feito tendo-se como referência seus sites. O Greenpeace afirma que seu objetivo é proteger o meio ambiente tentando inspirar as pessoas a mudarem atitudes e comportamentos. Desde 1971 atua no Canadá e a partir de 1990 no Brasil. Afirma manter-se apenas com dinheiro de campanhas e doações de seus "sócios", não aceitando ajuda de empresas ou partidos políticos.

A World Wide Fund Nature (WWF) é uma organização internacional criada em 1961 e atualmente possui sua sede na Suíça. No Brasil a WWF chegou em 1971 e trabalha em parceria com empresas, órgãos governamentais e não governamentais no seu objetivo de preservar espécies e ecossistemas.

Criada no Brasil no ano de 1986, a SOS Mata Atlântica tem por objetivo cuidar e proteger a Mata Atlântica e os ecossistemas sob sua influência. Através de projetos educativos visa fortalecer o conhecimento sobre este bioma e a conservação. Sobrevive através de doações de associados e não associados e de empresas por meio de parcerias.

O Instituto Socioambiental (ISA) foi fundado em 1994 e desde 2001 é uma OSCIP (Organização da Sociedade Civil de Interesse Público). Seu objetivo é propor soluções para questões sociais e ambientais "com foco central na defesa de bens e direitos sociais, coletivos e difusos relativos ao meio ambiente, ao patrimônio cultural, aos direitos humanos e dos povos". 
Quanto ao ritmo de publicação, observou-se que as ONGs começaram a abordar a crise nas notícias de 2014 no mês de março e são as nacionais que publicam mais ao longo do ano, de 35 notícias do grupo, 25 foram publicadas pelas ONGs brasileiras. As ONGs internacionais começaram a publicar em junho e juntas são as responsáveis por publicar 10 das 35 matérias do grupo e, coincidentemente, publicaram cinco cada uma. Em janeiro e fevereiro nenhuma ONG do grupo publicou notícias relacionadas com o tema. Em março, apesar de se comemorar o Dia Mundial da Água, o sistema Cantareira não foi pauta relacionada com esta comemoração nas ONGs internacionais. Em abril nenhuma das quatro ONGs publicou qualquer matéria sobre o tema. Os meses em que o grupo mais publicou sobre o sistema Cantareira foram junho, outubro e novembro. Apenas nesses três meses todos publicaram alguma matéria sobre o sistema Cantareira.

O Greenpeace publicou a primeira matéria sobre a crise em junho e ao longo do ano totalizou cinco. A SOS começou a pautar o tema a partir de março e foi aumentando gradativamente o número de notícias por mês, começando com uma e chegando, em dezembro, a quatro. Ao longo do ano publicaram-se 15. A WWF reconheceu a crise da água em São Paulo apenas em 5 de junho, quando se comemora o Dia Mundial do Meio Ambiente. Veicularam poucas e espaçadas notícias ao longo do ano, quando totalizaram 5. A primeira matéria no site do ISA saiu em março e ao longo do ano publicaram 10.

\section{Imagens e links}

Nas publicações do Greenpeace as imagens referiram-se a pessoas com máscaras do governador de São Paulo usadas em manifestações que ocuparam diversos espaços públicos com grande circulação de pessoas na cidade de São Paulo. Quando aconteceram na Rua Oscar Freire (que caracteriza-se pela presença de lojas de grife) vieram acompanhadas de uma faixa que dizia: Água virou luxo. O Greenpeace chegou a criar um evento com baldes de "ouro" para armazenar água fazendo alusão à ideia de que este recurso se transformou em um artigo de luxo. A criação de eventos é uma especialidade usada principalmente pelo Greenpeace na sua estratégia de midiatização da crise. Em uma das notícias foi utilizada uma charge em que é oferecido ao governador "um gole do volume morto".

A SOS optou predominantemente por imagens dos autores de artigos de opinião que publica, mas veiculou algumas que retrataram situações de desmatamento, já que a ONG abordou a crise da água atrelada à questão das florestas, sua razão de ser. Em matérias sobre mobilizações foram exploradas imagens de atos públicos. Noutras publicações havia imagens de uma pessoa coletando água para avaliação de qualidade ou outra ilustrando projetos de restauração florestal para o sistema Cantareira (a qual estava relacionada com o lançamento do edital pela ONG). Havia uma imagem institucional divulgando a Aliança pela Água, coletivo formado por entidades, especialistas e gestores.

A WWF foi econômica com as imagens: usou uma de manifestação e, em uma das matérias, ilustrou com fotografia do solo rachado pela seca. Já o ISA explorou vistas aéreas das represas e áreas rurais para evidenciar o desrespeito à legislação em relação à mata ciliar, fotografias de mananciais, banners, mapas, imagens de eventos em que a ONG esteve envolvida (Aliança pela Água), de área seca e imagens no Tumblr (fez uso exaustivo desse mecanismo publicando imagens de ótima qualidade).

Quanto aos links atrelados às notícias, o Greenpeace utilizou-os para direcionar a notícia para a carta entregue ao governador do Estado, para matérias anteriores, para o vídeo das manifestações, para propostas da 
Aliança pela Água e, ao longo das matérias, colocou links para aprofundar documentos e outros elementos que compuseram a notícia ou relacionadas a ela.

Os links da SOS remeteram a outras informações do próprio site e, também, do Facebook. Ao longo das matérias havia links para documentos e outros elementos que compuseram a notícia ou que estavam relacionadas com ela.

A WWF usou links de manifestos, vídeos no Youtube sobre ações criadas por eles, documentos do Água@ SP (propostas para enfrentar a crise criadas pela própria ONG) e link de transmissão do lançamento do evento.

Já o ISA aprofundou questões citadas nas matérias por meio de links que levaram a matérias no site que tinham palavras-chave relacionadas com a notícia, para vídeos do Youtube, para páginas de evento no Facebook e para informações sobre a procedência da água. Blogs e íntegras de documentos citados nas matérias também geraram a exploração de links.

\section{Contextualização}

Para o Greenpeace passado, presente e futuro se interligavam constituindo o tempo da crise. Do mesmo modo a SOS contextualizou o tema trazendo elementos causadores da crise, mas focou-se numa análise do presente apontando a necessidade de mudança em relação ao trato da água para se ter segurança hídrica no futuro (um futuro incerto). A WWF não deixou transparecer o tempo da crise. Já o ISA trabalhou no tempo futuro, baseado nas prescrições para a solução do problema.

O Greenpeace contextualizou a crise da água fazendo referência ao problema também em outros municípios de São Paulo, especialmente Itu e Campinas. Interpretou-se este como sendo um pequeno movimento de contextualização já que indicou, de forma genérica, que "especialistas" apontaram como as causas da crise a continuidade na retirada da água de modo não racional do sistema Cantareira, o desmatamento e a poluição do recurso, a seca, a falta de participação social e de transparência na gestão. Apesar de referir-se a previsões registradas e ao nível dos mananciais não informou, concretamente, sobre estes elementos (falta de precisão de dados). Apenas em uma notícia se referiu às bacias atingidas pela crise: Tietê e Piracicaba.

Para o Greenpeace a crise estava relacionada com problemas de gestão, desperdício, perdas, falta de eficiência no uso da água, necessidade de recuperação e proteção das florestas e matas ciliares no entorno das represas criando áreas protegidas e falta de implementação da Política Estadual de Mudanças do Clima (PEMC), que volta-se à redução de gases do efeito estufa.

Esta ONG abordou a crise hídrica do estado de São Paulo sob o viés primeiramente político e, secundariamente, ecológico. Na segunda notícia do ano o Greenpeace colocou-se como ator preocupado, que encaminha demandas estratégicas apontando soluções para atenuar e resolver uma crise cíclica. Para a ONG a escassez se agravou e a população estava desamparada pelo poder público. A água foi enquadrada como um artigo de luxo.

A ONG colocou-se como aquela que sabia sobre as crises de água, podendo julgar qual seria "a maior" sem, contudo, apontar dados. Divulgaram "previsões" sem indicar as fontes, e a questão hídrica foi adjetivada como algo grave: "pior" crise da história de São Paulo, sob ameaça de desabastecimento. Acusaram candidatos ao governo estadual e federal de deixarem soluções de lado nos debates.

Apesar de considerar tão grave a crise e de afirmar que os indícios da crise eram claros desde o início do 
ano, o Greenpeace só começou a noticiar o fato em junho no site, assumindo um tom generalista "atinge milhões de pessoas", "pacote bilionário”, “especialistas apontam”, carecendo de precisão de dados. Quando Alckmin e Dilma fizeram propostas estas foram consideradas caras e, ao mesmo tempo, paliativas dando a entender que não criariam segurança hídrica. A ONG deixou entrever que acreditava que não tomaram medidas firmes por ser um ano eleitoral (atribuiu o sentido de fraqueza aos atores). Considerou que as ações destes governos não resolviam o problema e não atacavam as causas, além de insistirem em erros, já que contrariavam as soluções que a organização propunha. "O colapso é praticamente certo" se mantido os níveis de chuva do ano anterior, antecipou. As matérias assumiram um tom profético também quando afirmaram categoricamente que a crise "provavelmente se estenderá por muitos anos". Também colocou-se como alguém que sabe da realidade.

Ao contextualizar a crise, a SOS referiu como suas causas: falta de chuva, descaso com os rios, alto consumo, poluição e desperdício (citou como principais responsáveis o setor público, agricultura e a indústria, apesar de propor que estas desperdiçassem menos e pagassem pelo que captavam), falta de investimentos, falta de saneamento (doméstico e industrial) e uso de defensivos agrícolas. A organização trouxe dados relacionados com a capacidade e limites dos reservatórios e de captação em relação à demanda. Fez referência à questão da outorga e aos organismos envolvidos para esta autorização: organismos nacional e estadual, além das bacias hidrográficas e o Ministério Público. Prioritariamente, a questão do desmatamento e do zoneamento urbano foram problemas relacionados com a crise nas publicações da SOS, apesar da questão energética também ter aparecido. Observou-se uma contextualização muito mais aprofundada nas notícias de caráter informativo do que nas publicadas pelo Greenpeace.

A ONG abordou principalmente elementos técnicos, legais, socioeconômicos no seu processo de midiatização, e o fez a partir de uma contextualização macrorregional. Diferentes fontes, estudos e dados são publicados de modo a "comprovar" o posicionamento da ONG. Ressaltou que a necessidade de planejamento e zoneamento urbano, se não atendida por falta de políticas públicas "eficientes" de habitação, saneamento e gestão ambiental, geraria ocupação e conflitos, além de acúmulo de processos. Defendeu que proprietários privados que ofereçam serviços ambientais sejam ressarcidos, que haja uma compatibilização entre "interesse social e atividades econômicas". Na sua abordagem ofertou elementos de serviço ao seu receptor indicando onde encontrar soluções. Também ofereceu dicas para o cidadão economizar água.

A crise da água foi enquadrada a partir de conflitos entre Estados (Rio de Janeiro e São Paulo) e entre municípios de São Paulo, entre sistema elétrico e hídrico. Seus posicionamentos legitimaram o papel dos comitês de bacias hidrográficas, conforme assegurado por lei. Ressaltaram a relação do desmatamento com a crise, o acirramento de conflitos e a necessidade da gestão compartilhada e integrada dos recursos hídricos com os comitês tendo seu papel respeitado. Apesar de ter colocado o sistema Cantareira como símbolo da crise, não foram tratados apenas problemas de São Paulo, mas também nacionais.

A WWF não contextualizou a crise, mas relacionaram-na com a seca, mudanças climáticas, falta de planejamento, falta de governança, desrespeito à legislação ambiental, ocupação irregular, aumento da demanda, uso irracional do recurso e crescimento populacional. Referiu-se também a outros problemas relacionados com a biodiversidade aquática, atividade de pesca e atividade turística, questão da saúde humana e custos de tratamento da água devido à utilização do volume morto.

Predominou uma abordagem pedagógica, ecológica e social nas publicações da WWF, o que se explicita quando chamaram a atenção para o risco de perda de diversidade aquática e mostraram-se preocupados com o 
impacto na economia da pesca na região e, também, na saúde humana. A crise foi permeada pela necessidade de mostrar-se uma oportunidade para repensar a gestão dos recursos hídricos.

O ISA apresentou uma contextualização mínima das diferentes represas do sistema Cantareira. A crise foi relacionada com problemas como a ocupação desordenada, despejo de esgotos, desmatamento, legislação flexível, grandes empreendimentos de infra-estrutura, poluição das fontes, "gestão com foco na oferta de fontes inesgotáveis de água”, ausência de participação e transparência, evento climático extremo e déficit de chuvas, além da degradação das represas. A crise teria sido agravada por medidas impopulares como multas e racionamento. A “inação política agravou o cenário da estiagem”, afirmou.

Em 31 de março foi publicada a primeira matéria da ONG acerca do problema do Sistema Cantareira com a diminuição de áreas de florestamento na bacia, portanto relacionando-a com os problemas florestais e abordando, principalmente, as mudanças no Código Florestal, não focando a crise da água em primeiro plano. Ela foi abordada a partir do risco de escassez, de sua intensidade, da necessidade de soluções urgentes que passavam pelo compromisso de diferentes atores sociais. A ONG discutiu o tema a partir da sua conexão com problemas nacionais. Buscou informar para "conscientizar" sobre a relação de cada um com a água, inclusive permitindo ao usuário saber de onde provém a água que ele acessa e as condições nas diferentes represas que compõem o sistema Cantareira, o que fez com uso de mapas, fotografias, informações textuais e exploração de imagens (de ótima qualidade).

Investigou e diagnosticou a situação do sistema Cantareira por meio de sobrevoos para produção de imagens e consulta a especialistas e parceiros para a construção de propostas para a resolução do problema de modo coletivo o que é sintetizado no documento Água@SP, decorrente de parcerias denominadas Aliança pela Água de São Paulo. Gerou informação a partir de si mesma e de sua rede de parceria. Praticamente todas as matérias foram de divulgação das propostas da Aliança pela Água SP e, assim, agendou outras ONGs. Em uma das matérias relacionou a crise à inação política e a decisões tomadas sem estudos devidos, citando a transposição do São Francisco que teria vitimado a população nordestina, portanto a matéria frisou "se não quiser 'secar', a sociedade brasileira deve reagir", mobilizando-se, recorrendo à mídia e exigindo decisões necessárias.

Ressaltou que a crise refia-se a questões técnica, ética, socioambiental e política, já que poderia gerar a privação de água, além de afetar o orçamento, a saúde, o ambiente e a dignidade dos cidadãos. Mas entendeu que, no entanto, o governo priorizou a dimensão técnica, preterindo as demais. De modo geral, salientou a corresponsabilização de todos por causas e soluções e pelo reconhecimento dos princípios de justiça social no que tange ao uso da água.

\section{Responsabilização}

Nas publicações do Greenpeace o governador do Estado foi envolvido como responsável pela crise. Em relação a ele são utilizados os seguintes sentidos: mau gestor dos recursos hídricos, inação, tomador de medidas paliativas (por usar o volume morto) e sem embasamento e estudos. O governador ignorou a carta enviada pelo Greenpeace o que, para a $\mathrm{ONG}$, foi interpretado como falta de preocupação com a questão, falta de transparência do governo, incompetência para dialogar com a população, incapacidade para medidas concretas com a adoção de medidas paliativas e eleitoreiras, o que não o caracterizou como um governo responsável. Para a ONG houve descaso do governo. O governador e a Companhia de Saneamento Básico do Estado de São Paulo (SABESP) 
teriam tomado apenas medidas irrelevantes como: incentivo à economia de água e uso do volume morto. $\mathrm{O}$ governador foi posto como negligente, como alguém que não teve coragem e não fez uma gestão cuidadosa. A responsabilidade pela crise hídrica foi atribuída pessoalmente ao governador Alckmin e não ao Estado. A partir dessa ênfase, o Greenpeace deixou de abordar a responsabilidade de outros atores institucionais e também dos moradores, e o comitê de bacias foi ignorado. $\mathrm{O}$ foco foi reduzido à má gestão do governador em primeiro plano e, em segundo, às mudanças climáticas.

Nas publicações da SOS o governador de São Paulo, candidato à reeleição, foi colocado como aquele que tentava "passar um clima de tranquilidade à população, o que não corresponde à gravidade da questão". Também a oposição foi referida como quem passava longe do debate sobre a crise hídrica. A ONG solicitou "ação urgente e firme do Governo do Estado", já que considerou que parte do problema deu-se pelas campanhas anunciadas "tardiamente pelo Governo do Estado", mas que mesmo assim tiveram adesão da população. Na quarta matéria do ano, a ex-presidente Dilma foi envolvida como corresponsável pelo problema. Em uma matéria foi citado o Conselho Estadual do Meio Ambiente (CONSEMA) como um ator que deveria ser chamado para definir as estratégias de conservação.

A SOS atribuiu a crise ao "fraco sistema de gestão do sistema hídrico". Em uma publicação referiu-se à "incapacidade" da ANA de promover uma gestão compartilhada da água, de dirimir conflitos e garantir acesso à população. No entanto, na mesma matéria, em seguida, já colocou a ANA como um órgão que atuava "de forma compartilhada com outros órgãos gestores dos Estados e seus sistemas de gerenciamento de recursos hídricos", demonstrando contradições quanto ao seu posicionamento. Adiante, a matéria deixou claro o posicionamento da ONG quando afirmou: "esperamos que a ANA e os Governadores de São Paulo e Rio de Janeiro reconheçam os Comitês de Bacias para planejamento e tomada de decisões. É preciso tratar a gestão da água de forma estratégica e integrada. [...]".

A WWF expôs o que entendeu ser o papel de cada um diante da crise hídrica: governos deveriam implementar políticas, instrumentos e orçamentos sobre o problema. As empresas deveriam seguir a legislação, reduzir o uso com inovação e interagir com a comunidade. O cidadão deveria economizar água, participar do comitê, fiscalizar e cobrar ações dos setores público e privado.

Nas matérias do ISA os governantes candidatos à reeleição foram criticados pela inação que teria agravado a crise. A ONG também legitimou a Aliança pela Água quando divulgou que o coletivo alertava: "não existe mais tempo, dinheiro e água para desperdiçar com conjunto de obras" que não vão resolver o problema. Também ressaltou que as obras bilionárias propostas pelos governantes não atacariam as suas causas e "adotar esse caminho é insistir no erro", já que não cuidaria de nascentes, não recuperaria águas exploradas, não reduziria consumo e perdas, portanto não seriam sustentáveis.

Governantes eram, nas publicações do ISA, atores que, ao tratar de políticas públicas, ignoraram estudos científicos (os quais a ONG validou já que salientou em várias matérias parcerias com “especialistas”). Também colocou que o governo tomava providências sem informações sobre a situação (como o grau de privação de água ou preços a serem pagos por grandes consumidores quando havia restrição hídrica). As decisões teriam sido tomadas "na ausência de avaliação qualificada das causas e dimensões da falta de água".

O ISA atribuiu a crise a governos de diferentes instâncias, empresas, agricultores e população em geral. A crise teria-se agravado "pela resistência dos governos em tomar medidas mais firmes em um ano eleitoral". Governos candidatos à reeleição "falham em responder à crise, não garantem transparência e participação da 
sociedade e não criam mecanismos robustos para promover a segurança hídrica do Estado”, afirmou.

Fontes

Quanto às fontes autorizadas a manifestarem-se nas notícias do Greenpeace são geralmente institucionais, como o diretor de políticas públicas da ONG ou o coletivo do qual faz parte, no caso da Aliança da Água, com as suas posições em relação à crise: cobrou ações imediatas e foi colocada como conhecedora da "real" situação do abastecimento da água em São Paulo, abordou aspectos sociais e climáticos a serem levados em conta para a superação da crise e amparou-se em uma lei estadual de recursos hídricos para legitimar o seu posicionamento, propondo economia, reuso, captação da água da chuva e redução de perdas. Também a Aliança solicitou um plano de contingência transparente que permitisse o enfrentamento continuado da crise, incluindo a necessidade de cuidado com as perdas por parte de diferentes tipos de usuários da água (agricultura, indústria, grandes consumidores urbanos), além da recuperação de fontes de água.

Por meio das pautas da Aliança da Água o Greenpeace ampliou as suas propostas e soluções. A Aliança pela Água teve a sua imagem construída como um grupo que lidava com a crise de modo compartilhado, com engajamento e por meio do diálogo entre diferentes segmentos da sociedade e do governo. A ONG, que participou deste coletivo, em outras publicações atacou diretamente o governo de São Paulo e federal, depreciando-os, sem mostrar o ponto de vista destes nas publicações, portanto sem dialogar.

O Greenpeace primou por ser fonte de suas publicações, das quais depreendeu-se que a crise era "seríssima" e as medidas tomadas pelo gestor do Estado de São Paulo eram paliativas e sem embasamento. A crise da água foi percebida em conexão com as questões climáticas.

A SOS nem sempre deixou claro nas informações que publicou quem seriam as fontes. Entre as fontes citadas ou consultadas apareceram os Comitês de Bacias Hidrográficas envolvidos na crise, dados da Organização das Nações Unidas (ONU) sobre demanda de abastecimento, estudo do Departamento de Água e Energia de São Paulo (DAEE), dados da Companhia de Saneamento Básico do Estado de São Paulo (Sabesp) e da Agência Nacional das Águas (ANA).

Gestores da própria SOS também foram citados como fontes únicas ou acompanhando outras, caso do Atlas de Remanescentes Florestais da Mata Atlântica, uma iniciativa conjunta da ONG com o Instituto Nacional de Pesquisas Espaciais (INPE), que realizou sensoriamento remoto e geoprocessamento para monitorar remanescentes florestais, projeto que teve patrocínio de Instituições privadas. A ONG atrelou o desmatamento à crise hídrica. Também a ONG Conservação Internacional, o Instituto Nacional de Pesquisas da Amazônia (INPA), o Instituto Internacional de Ecologia de São Carlos foram citados como fonte.

Portanto, as fontes são do campo dos movimentos sociais, governamental e científico, além de midiáticas, já que também se fez alusão a manchetes de notícias para ressaltar que o problema é "real". Foi citada explicitamente uma reportagem da Folha de São Paulo sobre a contenção do desperdício da água e a partir dessa matéria a SOS posicionou-se e prescreveu soluções para a crise. Portanto, usou de uma matéria publicada na mídia de massa como uma autorização para falar o que desejava e legitimar o seu discurso a partir do discurso do outro, gerando um processo de legitimações cruzadas. Também utilizaram-se de informações da Deustche Welle. De modo geral, as fontes autorizadas foram utilizadas para validar o posicionamento da ONG, que salientou-se por relacionar desmatamento e crise da água em tom pedagógico. 
A WWF tendeu a se colocar como fonte única de suas publicações, mesmo quando afirmou ser compromisso de governos, empresas e da sociedade civil a questão da água. Em uma das notícias a ONG abordou o que considerou serem as causas da crise (degradação de florestas, ocupação de áreas de mananciais, falta de planejamento do governo e falta de planejamento no setor). A ONG colocou-se como "especialista" para falar sobre a água. Estudo da SABESP foi citado em uma publicação, mas a SABESP não foi consultada. Houve, ainda, dados que não precisaram as fontes claramente.

Nas matérias do ISA ou não havia fontes ou a própria ONG era a fonte autorizada. Quando apresentou dados sem indicar diretamente a fonte, pecou pela imprecisão, como por exemplo, quando afirmou: "estimativas apontam".

\section{Agendamentos}

De modo geral quem agendou as organizações foram elas mesmas e/ou organizações sociais com as quais compactuavam ou formavam alianças, portanto evidenciou-se que houve agendamento entre as organizações.

No caso do Greenpeace, ao dar espaço às ideias da Aliança da Água, coletivo do qual fazia parte, gerouse um inter-agendamento entre quem participava desta rede e cooperava em seus posicionamentos diante do problema. A Aliança propôs-se a monitorar o poder público e a oferecer soluções para a crise. E o estudo Água@SP do ISA mapeou atores e propostas relacionadas com a crise e deu origem à Aliança pela Água. O documento apontou 196 ações de curto prazo (sintetizadas na segurança para enfrentamento da estiagem até abril de 2015) e 191 ações de longo prazo (que refereriram-se à implantação de um novo modelo de gestão sustentável e segura). Observou-se em algumas publicações contradições quanto ao número de ações propostas pelo documento defendido pela Aliança das Águas, o que caracterizou-se como imprecisão de dados da ONG.

No caso da SOS o inter-agendamento entre ONGs explicitou-se quando a Conservação Internacional foi citada como um dos autores de estudo sobre a questão da água. Também foi observado que a matéria publicada pelo Greenpeace intitulada "Por mais soluções reais e menos soluções bilionárias" foi replicada no site da SOS com o título "Conversa entre Alckmin e Dilma não abordou questões fundamentais sobre a água". Esta notícia estava acompanhada de uma imagem da Aliança da Água que convocava os interessados a participarem do movimento. Nesta publicação realizou-se uma forte crítica aos governos de São Paulo e federal, alegando-se que os mesmos trataram da crise de forma tardia, após as eleições. Também criticou a forma de lidarem com o problema por meio de obras hídricas, que demandariam um pacote milionário de investimento sem a criação de mecanismos robustos para garantir a segurança hídrica do Estado. De modo geral, a SOS apresentou dados sem fontes e em tom alarmista.

No caso da WWF também observou-se que a matéria publicada pelo Greenpeace "Por mais soluções reais e menos soluções bilionárias" foi replicada no seu site como "Em meio a pior crise hídrica da história do Estado de São Paulo, soluções fundamentais foram deixadas de lado na conversa entre Alckmin e Dilma".

O ISA apareceu como quem gerou o maior interagendamento entre as organizações por meio das propostas Água@SP, decorrente de estudo seu, que deu origem à Aliança pela Água.

Ao se analisar em que medida a própria organização foi promotora de uma ação e fonte da informação sobre a ação que noticiou, evidenciou-se que o Greenpeace utilizou-se da prática da auto-referencialidade reiteradamente: foi ela que promoveu, alertou, se preocupou, realizou protestos, definiu o tamanho da crise, 
definiu quem é incompetente e qual a solução da crise. A ONG colocou-se como julgadora dos atos do governo e como quem tinha as soluções para resolver o problema.

Quanto à SOS, a própria organização colocou-se como fonte na maioria das matérias, o que também denotou prática de autoreferencialidade. Tendeu a divulgar as suas ações e de parceiros. A ONG divulgou ações de restauração florestal em parceria com organizações privadas. Tinha a prática de republicar artigos assinados por pessoas da ONG ou nos quais ela foi fonte e que foram veiculados em outros ambientes virtuais: blogs, sites, jornais e a mídia de massa (nacionais e internacionais). Quando não publicava matérias externas eram publicados artigos de ações da própria ONG (mobilizações, editais). Eventualmente noticiaram a partir de uma demanda das questões externas, caso da aprovação de alguma lei.

A WWF colocou-se como quem praticava ações "consistentes e replicáveis", favoráveis a ecossistemas aquáticos de quatro biomas nacionais, informou sobre ações que tinham parceria com iniciativa pública e privada. Uma das notícias referia-se a um evento que a ONG participou promovido por outra organização em parceria com universidades. Sua prática era publicar desde que estivesse implicada e de modo positivo para a sua imagem.

O ISA divulgou informações e propostas que visaram discutir ou sensibilizar em relação à crise da água e eventos em que participou como promotor ou com parceiros que eram de organizações governamentais e não governamentais.

Quanto às soluções para a crise que as ONGs buscaram agendar para os seus públicos, identificou-se que o Greenpeace entendeu que passava pelo comprometimento do governo com a melhor gestão/eficiência dos recursos hídricos, o que se explicitou com a carta que enviou ao governador. Também entendeu que a solução passaria pelo combate ao desperdício, redução de perdas, eficiência no uso da água, recuperação e proteção das florestas e matas ciliares no entorno das represas criando áreas protegidas, implementação da Política Estadual de Mudanças do Clima (PEMC) para redução de gases do efeito estufa e taxação de quem não economizava água. Assumiu o tom irônico quando afirmou: "Seria bom também fazermos uma reza braba - em forma de pressão política - para que o governador Geraldo Alckmin acorde e assuma a responsabilidade que lhe foi conferida pela população - sob o risco da maior metrópole do Brasil entrar em colapso.”.

$\mathrm{Na}$ terceira matéria publicada no ano, o Greenpeace avançou nas propostas de soluções incluindo três elementos: inclusão do uso da água na agricultura, políticas que evitassem a ocupação em torno dos mananciais e saneamento para combater a poluição. Referiu-se, ainda, à necessidade de evitar a proliferação de poços artesianos potencialmente contaminados e reservas inadequadas de água. Também propôs a discussão pública de um plano de contingência e a difusão permanente de informações sobre a crise.

Para a SOS a solução para a crise passava pela proteção de Unidades de Conservação (UCs públicas e privadas), recuperação das Áreas de Preservação Permanente (APPs), restauração natural das nascentes e margens dos rios, combate ao desperdício e poluição, assim como de vazamentos e "gatos", garantia da segurança hídrica, monitoramento e fiscalização, campanhas educativas e evitar o racionamento. Além da preservação de APPs e UCs, propôs que as áreas de mananciais e remanescentes de mata nativa nos espaços urbanos fossem protegidos a partir de um planejamento e zoneamento municipal.

Também a SOS apoiava políticas públicas como o incentivo à diminuição do consumo por meio de bônus: "Consumidores precisam continuar a poupar", afirmou. Segundo a SOS os cidadãos deveriam cobrar investimento dos governantes já que a água é essencial, mas deveriam abrir mão de alguns confortos se necessário. Outras propostas referiram-se à cobrança pelo uso da água (especialmente do setor agrícola, por ter altos níveis 
de desperdício), pagamentos por serviços ambientais, gestão integrada e compartilhada das águas e mudanças na legislação.

A SOS chegou a apresentar proposta de metas aos candidatos das eleições de São Paulo. Para ela, as ações estaduais precisavam estar integradas, com planos e metas claras, com instrumentos de governo e gestão, além do estabelecimento de planos econômicos (PSA) destinados aos proprietários de terra, municípios e unidades de conservação; bem como deveria-se prever a participação da sociedade nos comitês e na elaboração de planejamento estratégico transparente para a gestão das águas, cabendo à sociedade a responsabilidade de cobrar do Governo de São Paulo ações mais firmes.

Para a WWF as soluções passavam pelo investimento em planejamento e gestão dos recursos hídricos, reforma dos sistemas de captação, tratamento e distribuição para diminuir o desperdício. A ONG apontou o racionamento e multa para desperdício como soluções geradoras de recursos para mitigar o problema.

O ISA fez uso de debates e eventos que ajudaram a promover para apontar soluções. Uma de suas estratégias foi a criação do projeto Água@SP, que pretendia “promover e divulgar informações sobre o tema; e articular e fortalecer a rede de organizações e atores comprometidos com o tema”. O documento Água@SP é baseado em três linhas de ação conjunta que sintetizava as propostas da ONG e seus parceiros: "1) Produção e divulgação de informações sobre a crise e suas soluções; 2) Mobilização da sociedade e dos governos para a construção conjunta de soluções; 3) Engajamento de atores para a construção de um pacto pelas águas de São Paulo.” Para a segurança hídrica o documento previa ações compartilhadas pela sociedade, corresponsabilização, engajamento e diálogo entre diferentes segmentos incluindo o governo. O documento Água@SP propõe uma agenda de dez ações urgentes relativas à gestão da crise, informação para a população, redução do consumo, multa, garantia de água em situação de emergência, ações para grandes consumidores como indústrias e agricultura e incentivo a novas tecnologias que permitissem a economia de água.

\section{Discussão}

Quando se analisaram os elementos que constituíram os modos de enquadramento da crise hídrica paulista, observou-se que o Greenpeace assumiu um tom falacioso em diversos momentos quando apelou ao medo e à emoção, explorou inconsistências e contradições, o ataque pessoal e a utilização de dados sem fontes. O tom das notícias publicadas foi também denuncista e acusador, crítico. Foi alarmista, quando referiu-se ao perigo do desabastecimento, que a escassez avançava da periferia para os bairros ricos e não havia garantia de solução do problema. Foi dramático, já que afirmou: "A crise é seríssima”, "gravidade do cenário", "crises com certeza se repetirão", "A inação de agora vai cobrar seu preço". O tom foi predominantemente pessimista e sensacionalista, alertando e apontando para uma responsabilização personificada no governador de São Paulo, enquanto a ONG colocou-se em um lugar de saber/poder apontar as soluções da crise. Observou-se que o Greenpeace, de modo a gerar aproximação ao leitor, também fez alusão a jargões populares ao longo do texto: "Por incrível que pareça", "seria bom fazermos uma reza brava", "salve-se quem puder", "a inação vai cobrar seu preço".

A SOS assumiu um tom alarmista: "São Paulo pode parar por falta de água", "a situação impõe um alerta", “necessidade urgente”, audiência “deve acirrar o conflito”. Noutros momentos o discurso era pedagógico: “todos temos que saber o tamanho da nossa pegada hídrica", explicou o que é outorga, explicou o ciclo hidrológico. O tom pedagógico foi coerente com a imagem que a ONG buscou criar de si quando ressaltou também 
outras ações de educação ambiental conservacionista, ou seja, o que é coerente com a imagem e a identidade da organização. Também assumiu o tom prescritivo e analítico baseado em dados com fontes imprecisas: "especialistas calculam”, "a água é vital para nossa sobrevivência”, "precisa ser evidenciada na agenda dos gestores", "tratar rios como descarta é o pior desperdício”, "buscar água em outras bacias é inviável”. Fizeram alusão de que a água é um ser vivo e pode ser extinto, por isso "Consumidores precisam continuar a poupar". Também utilizou-se de trocadilhos: "extinção da água", "falta da água no debate eleitoral”. A maior parte das matérias encerrou com uma frase de "apelo" à participação e ao envolvimento popular, explorando a primeira pessoa do plural: "teremos menos água", "a água é vital para nossa sobrevivência", "nossas florestas", "também contribuímos", "nossa responsabilidade". O discurso foi marcado por um tom convidativo para a participação popular, mas também denotou ironia ao substituir o nome original do PL 219, que propõe o programa de regularização ambiental, por "Lei do Desmatamento". Ao apresentar uma crítica a um projeto de lei estadual, a ONG também realizou uma crítica a uma lei federal (Código Florestal). O tom da notícia foi crítico, já que utilizou-se de expressões como "retrocesso", "prejuízos", "perspectiva ainda mais grave”. Em alguns casos, colocou-se como agente fiscalizador.

A WWF alertou que a gestão era "adequada”, colocando-se em um lugar de saber. Fez uma manifestação utilizando uma gota-da-água inflável, transformando a crise em oportunidade de marketing. Percebeu-se, ainda, que adotou uma linguagem empresarial. $\mathrm{O}$ tom foi de alerta e de alarme: "pior crise", "colapso de abastecimento de água no sistema Cantareira", "é a gota da água”. Se colocou comoquem tem o poder de saber e de indicar a "solução para o problema", misturando o tom pedagógico e o especializado.

O tom de urgência para a preservação e uso racional de água foi assumido pelo ISA, que assumiu o lugar de quem prestou um serviço por divulgar o evento de sensibilização em relação à crise envolvendo diversas organizações, mas o que prevaleceu foi o tom prescritivo, já que a maioria das notícias referiu-se a propostas do documento Água@SP de autoria da Aliança pela Água.

\section{ConClusão}

Tendo-se analisado as gramáticas de produção de discurso das quatro ONGs individualmente em relação aos elementos de análise (imagens e links, contextualização, responsabilização, fontes e agendamento), os quais foram sintetizados na leitura dos enquadramentos predominantes, busca-se nesta seção apresentar uma síntese conclusiva das marcas de cada organização para, ao final, cruzá-las, identificando semelhanças e diferenças.

As análises apontam que o Greenpeace seguiu a mesma lógica que marcou a organização ao abordar a crise da água de São Paulo: fez uso de eventos que exploravam o sensacionalismo e o humor crítico. Os links dos textos midiáticos foram usados para conectar dados e aprofundar a abordagem. As fontes autorizadas a falar nas notícias foram prioritariamente a própria $\mathrm{ONG}$, seguida pelas outras organizações sociais com que atuava em parceria e, em terceiro plano, fez uso de dados de fontes públicas, sem dar espaço de fala a atores deste campo. Justamente aqueles que foram prioritariamente responsabilizados pela crise: o governo de São Paulo. De modo bem menos expressivo, a crise foi atribuída às mudanças climáticas. A ONG é que agendou a si mesma, além do ISA, devido ao documento Água@SP e à Aliança das Água.

A SOS, da mesma forma, manteve a marca que a identifica ao abordar a crise da água: relacionou-a com o tema central da ONG, que é a defesa das matas. Os links que usou nas notícias serviram para conectar assuntos, 
mais que para aprofundar. Suas fontes de dados foram imprecisas, mas evidenciou-se que fala a partir de si, mas dá também espaço para outras organizações civis regionais e internacionais, e aos gestores públicos e das águas (estadual e federal), dos quais publicou informações de documentos que ofertaram. A mídia nacional e internacional também apareceu como fonte das notícias. Observou-se nas análises das suas notícias um processo de interagendamento entre ONGs. Quem agendou a SOS fo prioritariamente o Greenpeace e a Aliança das Águas, iniciativa do ISA. Das quatro ONGs foi a mais suscetível ao agendamento por outras organizações ambientais.

A WWF foi econômica com as informações e priorizou os próprios dados no seu processo de midiatização da crise hídrica. Foi a ONG que seguiu mais fortemente os padrões da comunicação organizacional. Tendeu a ser a fonte única de suas publicações, nas quais colocou-se como especialista, apesar de não identificar claramente as fontes de seus dados. Deixou-se agendar, no entanto, pelo Greenpeace, a outra organização internacional. Responsabilizou governos, empresas e cidadãos pela crise, por não cumprirem os seus papéis.

O ISA divulgou imagens conforme o seu foco de ação: a questão da terra. Os links remeteram ao aprofundamento das notícias, que tiveram a ONG como fonte e dados que não tiveram identificada sua origem. Esta é a ONG que mais agendou as demais, devido à estratégia de criar um documento prescritivo sobre como enfrentar a crise da Água. E foi a ONG menos agendada pelas outras.

De modo geral, verificou-se que as características de midiatização que marcaram as organizações mantêmse na abordagem da crise da água de São Paulo, e se revelaram nas imagens que predominaram: Greenpeace e suas manifestações, SOS e as matas, WWF e a autoimagem, ISA e as terras; que as ONGs tenderam a agendarem-se entre si demonstrando um trabalho enredado; que os links das notícias tiveram mais a função complementar que de aprofundamento; que a responsabilização pela crise foi majoritariamente designada ao governador de São Paulo e, secundariamente, a outros atores (governo federal, gestores do sistema hídrico, empresas, produtores rurais e cidadãos) ou a causas ecológicas; que todas priorizaram-se como fontes principais de suas notícias e, em plano secundário, abriram espaço para seus parceiros ou outras mídias, e também desfrutaram juntas da característica de ofertar dados imprecisos quanto às fontes.

O que diferenciou estas ONGs na midiatização da crise hídrica foram os tons que emergiram dos enquadramentos, sendo que as prescrições foram convergentes. O Greenpeace abordou o tema apontando um cenário futuro a partir das causas da crise atual. Relacionou a má gestão com a dimensão política, e ressaltou também elementos ecológicos e econômicos nas suas prescrições sobre o fato: era preciso melhorar a gestão do governador e a eficiência no uso da água, monitorar e taxar desperdícios, recuperar matas e proteger as águas, investir no saneamento e no combate da poluição, difundir informações, além de implementar políticas públicas de clima. Seu tom foi de denúncia, alarme, acusação, crítico, pessimista, sensacionalista, especialista que julga.

A SOS focou as causas para analisar o presente e apontar a necessidade de mudanças diante de um futuro incerto. Para isso explorou o tom alarmista, pedagógico, prescritivo, analítico, apelativo, crítico e especialista. Sua abordagem explorou as dimensões da gestão a partir do ponto de vista mais técnico que político, além de um viés ecológico, socioeconômico e legal. Neste sentido, o que propôs foi a restauração das matas e a proteção das águas, a eficiência dos usos e monitoramento de desperdícios, cobrança pelo uso da água e incentivo por meio de bônus para quem poupasse, pagamentos por serviços ambientais, educação ambiental e um cidadão fiscalizador, além da gestão compartilhada.

A WWF focou em aspectos de gestão e técnicos, com marcas da dimensão econômica. Foi o que se 
evidenciou quando propôs planejamento, melhorias na captação, tratamento e distribuição das águas, racionamento e multas. Eventualmente assumiu uma posição pedagógica ao abordar a crise sob o viés ecológico e social. Seu tom foi de alerta, alarmista, e falou de um lugar de especialista. Não se conseguiu vislumbrar o tempo percebido da crise por esta ONG.

Por fim, o ISA preocupou-se com o cenário presente e prescreveu soluções para um futuro em que a crise da água fosse minimizada. Seu tom foi de urgência, prescritivo, prestativo e sensibilizador. Isso evidenciou-se pela sua estratégia: investigou, gerou dados, informou e formou a rede Aliança da Água a partir do documento Água@SP. Prescreveu soluções a partir da geração e oferta de dados, atuando como um consultor informal da crise, que não foi legitimado pelo gestor público. A dimensão que esta ONG explorou foi a governança, já que focou na informação, mobilizou uma rede de atores e buscou a construção de um pacto, agendando por meio do Água@SP e da Aliança da Água.

Verificou-se na análise da midiatização da crise da água de São Paulo pelas quatro ONGs que os mapas para o olhar construído por cada uma expuseram movimentos que se cruzaram e se distanciaram mantendo as suas singularidades. Todas cobraram, propuseram, solicitaram, exigiram, julgaram, analisaram, explicaram, partilharam significados e acusaram. As análises deixaram entrever que a midiatização da crise não gerou um processo de construção de capital comunicacional socioambiental, mas a crise fez emergir este capital com a Aliança da Água, que reúne organizações, especialistas e gestores. Como as propostas não se revelaram em forma de ação dos gestores das águas, considera-se que se trata de um processo relativo, já que restrito em termos de atores.

Os resultados reiteram alguns apontamentos de outros estudos sobre a midiatização de temas ambientais por organizações da sociedade civil organizada. Mazzarino et al. (2015) identificaram e compararam os temas ambientais agendados por quatro grupos de sites: de mídias comerciais, de organizações não governamentais; de organizações governamentais e de portais especializados na temática ambiental. O método quantitativo foi utilizado, baseado na pesquisa bibliográfica e documental em 12 sites. A análise de conteúdo das 1907 notícias, publicadas entre outubro de 2011 e fevereiro de 2012, buscou compreender se organizações de naturezas diversas propõem agendas diferenciadas em relação às temáticas ambientais para seus públicos. O resultado do mapeamento feito por Mazzarino et al. (2015) revelou quais temas ambientais alcançaram a condição de notícia, assim como a periodicidade com que o internauta foi abastecido com informações. Entre os quatro grupos analisados no estudo indicado, os sites das ONGs Greenpeace, WWF, SOS Mata Atlântica e Instituto Socioambiental apresentaram o menor fluxo de informações sobre temas ambientais, sendo que focaram principalmente temas relativos a movimentos sociais e protestos; legislação, fiscalização, taxação e multa; editais; desmatamento; clima; e fauna. O tema água teve baixíssima aparição.

Gonçalves e Miguel (2012) analisaram a divulgação de temas científicos nos espaços virtuais usados pelo Greenpeace e concluíram que a organização não atuava no sentido de promover a compreensão pública da ciência, já que a oferta era fortemente política, persuasiva, fragmentada, provocando uma participação restrita dos internautas, sendo que as manifestações eram filtradas pelo moderador, o qual não dava um fio condutor ao debate. Em outro estudo Miguel (2010) analisou a homepage do Greenpeace e conclui que a organização divulgava a causa ambiental, conquistava adeptos e fazia alertas, mas também reiterava práticas próprias da mídia tradicional ao informar de modo descontextualizado e em tom sensacionalista.

Em estudo sobre a cobertura da crise hídrica paulista, Martirani e Peres (2016) verificaram que os veículos 
dos movimentos sociais adotaram um enquadramento mais interpretativo que os outros. Um dos elementos avaliados pelas autoras foram as fontes. Segundo elas, o espaço dado a promotores públicos, ONGs, pesquisadores e especialistas nas notícias emprestaram uma postura crítica em relação ao governo de São Paulo.

\footnotetext{
"Se, no início da crise, a responsabilidade pela problemática da falta de água em São Paulo foi atribuída às mudanças climáticas e desperdício, com o processo de agendamento, apropriação da temática na esfera pública e atuação dos movimentos sociais, pôde-se observar um deslocamento, em que foi-se atribuindo, progressivamente, mais e mais responsabilidade ao Poder Público, ao governo do Estado e concessionária de abastecimento, com destaque à falta de transparência das decisões e medidas tomadas." (Martirani e Peres, 2016, p. 12).
}

As autoras concluíram que os veículos de comunicação das ONGs ajudaram a enriquecer o debate quando “apontaram privilégios e desigualdades na relação com consumidores, falta de transparência e inação por parte do Governo, além de irresponsabilidade por priorizar interesses eleitorais e não adotar uma política explícita de racionamento." Do mesmo modo a SABESP foi "percebida e enquadrada como omissa" (Martirani e Peres 2016, p. 14).

Concluiu-se que as quatro ONGs, a midiatizarem a crise da água em São Paulo, restringiram-se a informar de forma esparsa e a partir, predominantemente, de seus pontos de vista, algumas vezes pouco plural em fontes e perspectivas, quando poderiam ter instigado os internautas ao debate em seus espaços de mídia on line. Mesmo tendo enriquecido o debate, por agir sem as restrições impostas pelo campo jornalístico, esperava-se que a midiatização das organizações da sociedade civil mantivesse lógicas produtivas mais próximas do jornalismo público ou cívico, o qual guia-se pela função de melhorar a vida pública, tem compromisso com a democracia e com o fortalecimento da cultura cívica, pois se pensa como parte da sociedade e assume-se como um ator preocupado com o interesse da comunidade, que quer interferir na construção do espaço público suscitando o debate.

Pressupõe-se que a discussão dos temas públicos organiza processos de cidadania e governança voltados para as questões ambientais, gerando-se a capacidade e possibilidade dos cidadãos influenciarem as políticas públicas. Campelo (2012, texto digital) afirmou que "a visibilidade midiática foi importante no processo de transformação dos problemas ambientais em assuntos discutidos, e depois como impulsionadora para a elaboração de políticas públicas". Para esta autora, os meios de comunicação possibilitam o desenvolvimento social e o enfrentamento da crise ambiental, já que são "informativos e formativos, sendo com isso de suma importância na construção de uma percepção ambiental complexa; na promoção de mudança de hábitos e valores; na mobilização da ação pública em torno da criação de políticas públicas socioambientais”.

É preciso considerar, no entanto, que mesmo apresentando limitações quando se analisa criticamente o fazer das organizações, as práticas das ONGs contribuíram com o ambientalismo no que tange à oferta de uma perspectiva complementar à mídia de massa para entender a articulação dos múltiplos processos que integram a relação sociedadenatureza. Isto porque o ambientalismo problematiza a racionalidade social imposta pela ordem econômica dominante (Leff 1991).

Trata-se de um movimento relativamente novo. No Brasil, foi a partir da década de 1980 que começou-se a perceber a mídia como um espaço de visibilidade para as causas ambientais. As denúncias dos ambientalistas foram responsáveis pelo aumento da percepção da sociedade sobre esta problemática. Para Leff (1991) a crise ambiental gerou novas orientações para o processo de desenvolvimento e novas demandas para os movimentos sociais, sendo que é nos países da América Latina que este fato adquire importância estratégica para o desenvolvimento da 
consciência ambiental, o que possibilitou mobilizar atores políticos para a transformação das relações e formas de produção, já que os movimentos sociais surgiram contrapondo-se aos regimes totalitários e antidemocráticos.

\begin{abstract}
“[...] Los movimientos sociales se forman comunicando mensajes de rabia y esperanza. La estrutura concreta de comunicación de una sociedad conforma en gran medida los movimientos sociales. En otras palabras, los movimientos sociales y políticos, insurgentes o no, florecen y viven en el espacio público. El espacio público es el espacio de la interacción social y significativa donde las ideias y los valores se forman, se transmiten, se respaldan y combaten; espacio que en última instancia se convierte en el campo de entrenamiento para la acción y la reacción. [...]" (Castells, 2009, p.395).
\end{abstract}

Por fim, evidencia-se que o espaço público midiático, especialmente aquele propiciado pela internet, está aberto à ação comunicativa, constituindo-se em um lugar cada vez mais ocupado pelos diferentes atores sociais, que precisam, ainda não raras vezes, construir uma ocupação mais estratégica para engajar as pessoas em processos de cidadania ambiental.

\title{
Agradecimentos
}

Agradecemos ao Conselho Nacional de Desenvolvimento Científico e Tecnológico (CNPq).

\section{REFERENCIAS}

Campello LOS. 2012. A contribuição do jornal Gazeta de Sergipe para a discussão da problemática ambiental entre os anos de 1972 e 1992: o papel da imprensa escrita para o desenvolvimento social. In: Razón y Palabra, n. 80, ago/oct. Disponível em: <http://www.redalyc.org/articulo.oa?id=199524426019>. Acesso em 15 de abril de 2013.

Castells M. 2009. Comunicación y poder. Madrid: Alianza Editorial. 679 p.

Gonçalves EM e Miguel K. 2012. Conhecimento científico e participação social na cibercultura do Greenpeace. Revista Famecos. 19 (2), 438 - 457.

Leff E. 1991. Saber ambiental: sustentabilidade, racionalidade, complexidade, poder. Petrópolis, RJ: Vozes. 494 p.

Martirani LA, Peres IK. Jan./Mar. 2016. Crise hídrica em São Paulo: cobertura jornalística, percepção pública e o direito à informação. Ambiente e Sociedade. 19 (1) Disponível em: < http://www.scielo.br/pdf/asoc/ v19n1/pt 1809-4422-asoc-19-01-00001.pdf>. Acesso em 3 de fevereiro de 2017.

Matos H. 2009. Capital social e comunicação: interfaces e articulações. São Paulo: Summus. 277 p.

Mazzarino JM. 2010. O Campo Jornalístico, a Formação da Opinião Pública e a Emergência do Capital Comunicacional Socioambiental. XXXIII Congresso Brasileiro de Ciências da Comunicação - Caxias do Sul, RS - 2 a 6 de setembro de 2010. Anais do XXXIII Congresso Brasileiro de Ciências da Comunicação. Disponível em < http://www.intercom.org.br/papers/nacionais/2010/resumos/R5-1017-1.pdf> Acesso em 26 de maio de 2012. 
Mazzarino JM, Behs MV e Mantovani TP. 2015. Notícias ambientais em sites de mídias comerciais especializados em meio ambiente, de organizações não governamentais e governamentais. Revista Passagens, 6: 244-262

Miguel KG. 2010. Estratégias de comunicação e mobilização na cibercultura ambientalista. XXXIII Congresso Brasileiro de Ciências da Comunicação - Caxias do Sul, RS - 2 a 6 de setembro de 2010 Anais do XXXIII Congresso Brasileiro de Ciências da Comunicação. Disponível em < $\underline{\text { http://www.intercom.org.br/papers/ }}$ nacionais/2010/resumos/R5-2841-1.pdf> Acesso em 7 de fevereiro de 2017.

Moraes R. Mergulhos discursivos. 2007. In: Metodologias emergentes de pesquisa em educação ambiental. $2^{\mathbf{a}}$ edição. Galiazzi MDC, Freitas JV (orgs) Ijuí: Ed. Unijuí. p. 85-114

Santos R. 1997. A negociação entre jornalistas e fontes. Coimbra: Livraria Minerva. 215 p.

Verón E. 2004. Fragmentos de um tecido. Trad. Vanise Dresch. São Leopoldo: Editora Unisinos. 286 p. 